\title{
in Vitro Et'e Karşı Olan Tutumun Araştırılması: Erzurum Meslek Yüksekokulu Öğrencileri Örneği
}

\author{
Alper BARAN ${ }^{1, a, *}$ \\ ${ }^{1}$ Atatürk Üniversitesi, Teknik Bilimler Meslek Yüksekokulu, Gıda Kalite Kontrol ve Analizi Programı, Erzurum, Türkiye. \\ aORCID: 0000-0002-3089-6624
}

Özet: Artan dünya nüfusu nedeniyle ete olan talep günümüzde sürekli olarak artmaktadır. Mevcut kaynakların yetersiz oluşu, etik kaygılar, hayvan refahı gibi faktörler alternatif et kaynaklarının keşfi konusunda yeni çalışmalar yapmaya teşvik etmektedir. Bu alternatiflerden biri de temelde bir laboratuar ortamında üretilen in vitro ettir (IVE). IVE oldukça yeni ve bilinmeyen bir alternatif olduğundan, tüketicilerin ürüne karşı algılarının ve algılarını etkileyen parametrelerin ortaya konulmasıyla ilgili çalışmalara ihtiyaç duyulmaktadır. Bu bağlamda, mevcut araştırmamız, IVE'ye karşı genel tutumları araştırmak ve tüketicilerin tutumları üzerinde bazı öngörücü faktörlerin bir etkisi olup olmadığını incelemek için kurulmuştur. Çalışma Atatürk Üniversitesi Erzurum Meslek Yüksekokulunda okuyan 80 erkek ve 81 kadın öğrenci katılımcı kullanılarak kurulmuştur. Katılımcılara sorulan tüm sorular $1 \pm 5$ likert tipi ölçekte sunulmuştur. Katılımcılar IVE'yi denemeyeceklerini belirttiyse, diğer takip soruları sunulmamıştır. Daha sonra tüm katılımcılara, hangi koşullarda IVE'yi denemek istemeyeceklerini araştıran çok yönlü bir seçenek verilmiştir. İstatistiksel analizler, öğrencilerin bir şekilde IVE tüketmeye istekli olduklarını göstermektedir. Diğer taraftan IVE tüketimi konusunda tat/görünüşün öncelikli engel olduğu belirlenmiştir. Bununla birlikte, cinsiyet ve et türünün, IVE'ye yönelik tutumda en önemli değişkenler olduğu tespit edilmiştir. Ancak elde edilen tüm sonuçlar IVE algısı konusunda derin bir karmaşının olduğunu göstermektedir. Çalışma küçük ölçekli olsa da, IVE'ye yönelik algıların ölçülmesinde önemli bir adım olduğu ve IVE konusu hakkında daha fazla araştırmanın gerekliliğini ortaya koymuştur.

Anahtar Kelimeler: In vitro et, Öğrenciler, Tutum.

\section{A Survey on the Investigation of Attitude Against In Vitro Meat: An Example of Erzurum Vocational School Students}

\begin{abstract}
The demand for meat is constantly rising due to the increasing world population. Factors such as insufficient resources, ethical concerns, and animal welfare encourage the new studies to discover alternative meat sources. One of these alternatives is in vitro meat (IVM), which is produced in a laboratory condition. Since IVM is a fairly new and unknown alternative, studies are needed to find out consumers' perceptions and parameters that affect their perception. In this context, our current research was established to investigate general attitudes towards IVM and to examine whether some predictive factors have an impact on consumers' attitudes. The study was established using 80 male and 81 female students attending Atatürk University Erzurum Vocational School. All questions asked to the participants are presented on a $1 \pm 5$ likert type scale. If the participants stated that they would not try IVM, other follow-up questions were not submitted. Then, all participants were given a versatile option, which investigated under what conditions they would not want to try IVM. Statistical analysis shows that students are somehow willing to consume IVM. On the other hand, it has been determined that taste/appearance is the primary obstacle in terms of IVM consumption. At the same time, it has been determined that gender and meat type are the most important variables in attitude towards IVM. However, all the results show that there is a deep confusion about the perception of IVM. Although the study is small-scale, it has revealed that it is an important step in measuring the perceptions of IVM and the need for further research on the subject of IVM.
\end{abstract}

Keywords: In vitro meat, Attitude, Students.

\section{Giriş}

Gelişmekte olan ülkelerde, nüfus ve gelir büyümesinin kişi başına daha fazla hayvansal kaynaklı protein tüketimine neden olduğu ve bu şekilde et tüketiminin 2050 yılına kadar yaklaşık \%73 oranında artacağı tahmin edilmektedir (McLeod, 2011). Ancak et üretiminin gerçekleştirildiği mevcut tesisler, yeraltı suyu kirliliği ve sera gazı emisyonları gibi çevresel etkilerin yanı sıra hastalıkların kaynağı olma potansiyeli ve hayvan refahı gibi sebeplerden ötürü önemli bir endişe kaynağıdır (Bryant ve Barnett, 2018). Bu endişeler, protein kaynağı olan besinlere olan talebin önümüzdeki on yıllar boyunca artmaya devam edeceği tahminleriyle birleştiğinde, daha sürdürülebilir, besleyici ve hayvan refahına duyarlı üretim yöntemlerine acil ihtiyaç olduğu görüşünü ortaya çıkarmıştır. Bu noktada çözüm için son yıllarda ortaya çıkmış olan terimlerden biri de 
hücresel tarımdır. Bu yöntemle laboratuvar koşullarında kültürleme teknikleri kullanılarak tipik olarak hayvancılıktan elde edilen ürünler üretilebilmektedir. Doku mühendisliğine dayalı hücresel tarım, canlı hayvanlardan alınan hücre veya hücre hatları kullanılarak in vitro et (IVE) üretimine de imkân tanımaktadır. Bu yöntemle geleneksel hayvancılık yöntemlerine kıyasla minimum miktarda hayvansal doku ile yüksek miktarda tüketilebilir niteliğe sahip doku üretmek mümkün olabilmektedir. Başlangıç materyali olan hücreler, bir biyopsi prosedürü kullanılarak bir hayvandan alınabilmektedir (Post ve ark., 2014; Stephens ve ark., 2018).

Günümüzde bu amaca yönelik olarak $A B D$, Hollanda ve İsrail'de faaliyet gösteren sırasıyla Memphis Meats, MosaMeat ve The Kitchen Foodtech Hub adlı firmalar tarafından prototip IVE üretimi yapılmış ve henüz ticari olarak mevcut olmasa da beş yıl içinde IVE'nin ticari olarak satışa sunulacağı tahmin edilmektedir. Bazı araştırmacılar tüketici kabulünün IVE'nin önündeki en büyük engel olabileceğini ileri sürmüşseler de IVE'nin ticari bir boyut kazanması ve GDO'lar gibi benzer gıda teknolojilerinin tüketici tarafından yaygın bir şekilde reddedilmesi göz önüne alındığında, artık IVE'nin tüketici tarafından kabul görmesine yönelik giderek artan önemli bir ilgi mevcuttur (Stephens ve ark., 2018; Sharma ve ark., 2015).

IVE'nin tüketici tarafından kabul görüp görmeyeceği son yıllarda çeşitli çalışmalara konu olmuştur. Stephens ve ark. (2018) yakın bir zamanda bunu sistematik bir incelemenin parçası olarak araştırmışlardır. Bununla birlikte IVE'ye olan ilgiye yönelik bu türden birçok çalışma yayınlanmıştır. Bu bağlamda ülkemizde henüz bu konuyu irdeleyecek anket düzeyinde toplumun algılarını ölçmeye yönelik yapılmış bir çalışma bulunmamaktadır. Bu açıdan mevcut araştırmamızda küçük ölçekli olarak Erzurum Meslek Yüksek Okulu'nda IVE'e yönelik algıların ortaya konulması hedeflenmiştir. Elde edilen bulguların, yeni gıda teknolojilerini kamuoyunda anlamaya çalışan araştırmacılar ve endüstride IVE geliştiren araştırmacılar için yararlı olacağı umulmaktadır.

\section{Materyal ve Metot}

Deneysel tasarım: Eylül ve Kasım 2019 arasında yapılan yüzyüze bir anketle IVE olan algılar incelenmiştir. Bu ankete katılım tamamen anonim ve gönüllü olarak belirlenmiş ve anket başlangıcında bu durum katılımcılar tarafından onaylanmıştır. Veri toplamak için hazır bir potansiyelinin bulunması ve güncel teknolojik gelişmelerden yaygın medya aracılığıyla bilgi sahibi olma potansiyeli yüksek olan genç popülasyon yoğunlukta olduğu için Erzurum Meslek Yüksekokulu bu anketin yeri olarak seçilmiştir.

Illk olarak katılımcılara yaşları, cinsiyetleri, eğitim düzeyleri, yıllık gelirleri ve et tüketimleri hakkında sorular sorulmuştur. Bunu takiben katılımcılardan IVE'ye olan algıları sorulmuştur. Tüm katılımcılara katılımdan önce tasarlanan deneme hakkında kısa bir bilgilendirici metin verilmiştir. Anket soruları Wilks ve Phillips (2017)'in bildirdiği şekilde düzenlenmiştir (Ek 1).

Katılımcılara, IVE'yi normal ete göre nasıl algıladıkları hakkında bir dizi soru sorulmuştur. Bu sorular 1 (çok daha fazla) ile 5 (çok daha az) arasında değişen Likert tipi bir ölçekte sunulmuştur. Bunu takiben katılımcılardan, IVE'nin ticari olarak mevcut olduğunu ve tekrar Likert tipi bir ölçekte (1 (kesinlikle evet)- 5 (kesinlikle hayır)) denemek isteyip istemediklerini konusunda cevap istenmiştir. $1 \pm 4$ arasında bir seçenek belirlediyse katılımcılardan, bu ürünü satın alma, deneme ve tüketme isteklerini ve normal ete göre ne kadar para ödemek istediklerini inceleyen bir dizi soru sorulmuştur. Tüm sorular $1 \pm 5$ likert tipi ölçekte sunulmuştur. Katılımcılar IVE'yi denemeyeceklerini belirttiyse, diğer takip soruları sunulmamıştır. Daha sonra tüm katılımcılara, hangi koşullarda IVM'yi denemek istemeyeceklerini araştıran çok yönlü bir seçenek verilmiştir. Katılımcılara daha sonra şu anda hangi et türlerini yediklerini ve in vitro yöntemlerle üretildikleri takdirde hangi et türlerini yemek isteyeceklerini irdeleyen iki çok cevaplı soru daha verilmiştir.

İstatiksel analizler: Veriler, SPSS istatistik programı kullanılarak analiz edilmiştir. Analizler, hem ikili hem de çok değişkenli lojistik regresyon ile gerçekleştirilmiştir. Lojistik regresyon modelleri için logit link fonksiyonu kullanılmıştır. Normal et ve her bir et çeşidinin IVE'sini yiyeceğini bildiren katılımcıların oranındaki farklılıklar, çiftler halinde Fisher's Exact testi ile analiz edilmiştir.

\section{Bulgular}

Bu çalışmada, Türkiye'de ilk defa IVE'ye yönelik tutumlar küçük ölçekli olarak Erzurum Meslek Yüksekokulu öğrencilerinde incelenmiştir. Ankete yaşları 18 ile 37 arasında (Ort=21,7, SS=2,9) değişen toplam 161 katılımcı ( 80 erkek ve 81 kadın) dahil edilmiştir. Katılımcılara ait istatistiki bilgiler Tablo 1 'de verilmiştir. Ankete katılım gösterenlerin IVE ile ilgili algılarının ölçülmesi için sorulan sorular ve alınan cevaplara ilişkili oranlar Tablo 2'de verilmiştir. Anket katılımcılarının doğal yollarla elde edilen ete göre IVE algılarına dair sonuçlar Tablo 3 'te gösterilmiştir. IVE'ye yönelik bireylerin mevcut sahip olduğu tutumlarını açıklayan ifadelere karşılık 
alınan yanıtlar Tablo 4'te gösterilmiştir. Ankete katılanların önemli bir öngörücü faktör olan cinsiyetlerine göre IVE'ye yönelik algılarının yer aldığı istatiksel analizler Tablo 5'te gösterilmiştir.

Tablo 1. Araştırmada kullanılan demografik yanıtlar

\begin{tabular}{lcc}
\hline \multicolumn{3}{c}{ Kategorik Değişkenler } \\
\hline Soru/cevap seçenekleri & Cevap sayısı & Oran (\%) \\
\hline Cinsiyet & & \\
\hline Erkek & 80 & 49,7 \\
Kadın & 81 & 50,3 \\
\hline Gelir & & \\
\hline$>10000$ TL & 18 & 11,2 \\
2000-3000 TL & 103 & 64,0 \\
3000-4000 TL & 6 & 3,7 \\
4000-5000 TL & 23 & 14,3 \\
6000-7000 TL & 10 & 6,2 \\
8000-9000 TL & 1 & 0,6 \\
\hline Gıda Tüketim Alışkanlıkları & & \\
\hline Kırmızı Et & 127 & 78,9 \\
Sadece balıketi & 1 & 0,6 \\
Sadece tavuk eti & 27 & 16,8 \\
Vegan & 2 & 1,2 \\
Vejeteryan & 4 & 2,5 \\
\hline Diğer Değişkenler & 39,6 \\
\hline & & \\
\hline Yaş & & \\
Diyeti oluşturan et yüzdesi & Ortalama (0) \\
\hline
\end{tabular}

SS: Standart sapma

Tablo 2. Katılımcıların IVE ile ilgili algıları.

\begin{tabular}{|c|c|c|}
\hline IVE denemek ister misiniz? & Cevap sayısı & Oran (\%) \\
\hline Emin değilim & 34 & 21,1 \\
\hline Evet muhtemelen & 32 & 19,9 \\
\hline Evet kesinlikle & 30 & 18,6 \\
\hline Hayır kesinlikle olmaz & 45 & 28,0 \\
\hline Hayır muhtemelen değil & 20 & 12,4 \\
\hline \multicolumn{3}{|c|}{ Düzenli olarak IVE yer misiniz?* } \\
\hline Emin değilim & 39 & 40,6 \\
\hline Evet muhtemelen & 17 & 17,7 \\
\hline Evet kesinlikle & 3 & 3,1 \\
\hline Hayır kesinlikle olmaz & 12 & 12,5 \\
\hline Hayır muhtemelen değil & 25 & 26,0 \\
\hline \multicolumn{3}{|c|}{ Normal et yerine IVE yemeye istekli misiniz? * } \\
\hline Emin değilim & 41 & 42,7 \\
\hline Evet kesinlikle & 6 & 6,3 \\
\hline Evet muhtemelen & 14 & 14,6 \\
\hline Hayır kesinlikle olmaz & 9 & 9,4 \\
\hline Hayır muhtemelen değil & 26 & 27,1 \\
\hline \multicolumn{3}{|c|}{$\begin{array}{l}\text { Eğer IVE satın alacak olsaydınız, normal ete kıyasla ne } \\
\text { kadar ödemek isterdiniz? }\end{array}$} \\
\hline Biraz daha & 6 & 6,3 \\
\hline Biraz daha az & 42 & 43,8 \\
\hline Daha az & 38 & 39,6 \\
\hline Ne fazla ne eksik & 10 & 10,4 \\
\hline
\end{tabular}

*IVE denemeye istekli olmadığını (kesinlikle ve muhtemelen hayır) bildiren katılımcılar sonraki soruların dışında tutulmuştur.

\section{Tartışma ve Sonuç}

Elde edilen sonuçlar, öğrencilerin büyük bir çoğunluğunun IVE tüketmeye istekli olduklarını göstermektedir. Katılımcıların yaklaşık üçte biri IVE'yi (muhtemelen ya da kesinlikle) deneyebileceğini, yine yaklaşık üçte biri ise bunu deneyemeyeceğini (muhtemelen ya da kesinlikle) belirtmiştir. Bununla birlikte, düzenli olarak IVE yiyebileceğini belirten katılımcı sayısı düşüktür. Bu bağlamda katılımcıların yaklaşık beşte biri düzenli olarak IVE yiyebileceğini belirtmiştir (muhtemelen veya kesinlikle). Bu durum, katılımcıların IVE denemeye istekli olmasına rağmen, düzenli olarak tüketime dair daha güçlü çekincelere sahip olduğunu göstermektedir. Yapılan benzer çalışmalarda (Wilks ve Phillips, 2017; Slade, 2018; Hocquette ve ark., 2015) da genel olarak, çoğu tüketicinin IVE'yi denemek istediği, ancak nispeten küçük bir oranın normal et veya diğer et alternatiflerine göre seçeceği gösterilmiştir. Pratikte bu tercihin tat, fiyat ve popülerlik gibi bir dizi faktöre dayalı olduğu düşünülmüştür. Ancak IVE üretimi şu anda ticari olarak mevcut olmadığından, bunları net olarak açıklamak için henüz erken olduğu düşünülmüştür.

IVE tüketimine katılım için potansiyel engeller 4 kategoride toplanmıştır. $\mathrm{Bu}$ nedenleri belirten katılımcılardan \% 35'i ( $n=82$ ) ürünün tat/görünüşü, \% 27'si ( $n=63$ ) etik kaygı, \% 14'ü dini gerekçeler ( $n$ = 33) ve \% 19'u ( $n=45)$ diğer sebeplerden ötürü IVE tüketimine mesafeli yaklaşmaktadır. Tüm sonuçlar göz önünde bulundurulduğunda tat/görünüşün öncelikli engel olduğu ve ardından etik kaygı olduğu görülmektedir. Bu bulgular tat/görünüşün IVE tüketim uygulamalarına katılmanın önündeki en önemli engel olduğunu öne süren önceki araştırmalarla uyumludur (Bryant ve ark., 2019; Stephens ve ark., 2018; Tucker, 2014; Wilks ve Phillips, 2017).

Mevcut araştırmamızda katılımcılara ön bilgilendirme yapılarak konu hakkında kısa bir bilgi verilmiştir. Yapılan konu ile ilgili diğer çalışmalarda kabul ölçümlerinin önceden yapılan bilgilendirmeye duyarlı olduğunu göstermektedir. Örneğin Verbeke ve ark. (2015a), katılımcılara çevre ve halk sağlığı için faydaları hakkında ek bilgi verildiğinde kendilerine bildirilen IVE için daha fazla deneme, satın alma ve daha fazla ödeme yapma istekliliğinin arttığını tespit etmişlerdir. Bu bulgu, Bekker ve ark. (2017) ve Marcu ve ark. (2015) tarafından da bildirilmiştir. Ancak mevcut araştırmamızda bu durumun değerlendirilmesine yönelik bir ölçüm yapılmamıştır.

Hem normal ete kıyasla hem de IVE'ye yönelik genel algılar incelenmiştir. Katılımcılar, IVE'nin daha az sağlıklı, daha az doğal, daha az çekici, normal ete 
Tablo 3. Normal ete kıyasla ortalama IVE algıları ( 1 çok daha fazla - 5 çok daha az).

\begin{tabular}{lcc}
\hline Sorular & Ortalama & SS \\
\hline Sizce IVE'nin, normal etle karşılaştırıldığında ne kadar sağlıklı olduğunu düşünüyorsunuz? & 3,93 & 1,20 \\
Sizce IVE'nin normal etle karşılaştırıldığında ne kadar doğal olduğunu düşünüyorsunuz? & 4,28 & 1,03 \\
Sizce IVE'nin, normal ete kıyasla ne kadar çevre dostu olduğunu düşünüyorsunuz? & 3,13 & 1,47 \\
Sizce IVE'nin normal et ile karşılaştırıldığında ne kadar etik olduğunu düşünüyorsunuz? & 3,60 & 3,89 \\
Sizce IVE'nin normal et ile karşılaştırıldığında ne kadar çekici olduğunu düşünüyorsunuz? & 1,22 \\
Sizce IVE'nin, normal et ile karşılaştırıldığında ne kadar lezzetli olacağını düşünüyorsunuz? & 4,11 \\
Hayvanlardan insana bulaşıcı hastalık transferi için IVE ile normal et karşılaştırıldığında riskinin ne & 1,09 \\
kadar olacağını düşünüyorsunuz? & 3,49 \\
Küresel düzeyde, et talebinin karşılanmasında laboratuvarda üretilen etlerin kullanılması, normal & 1,37 \\
etten daha ucuz veya daha pahalı olacağını düşünüyor musunuz? & 2,79 \\
\hline
\end{tabular}

Tablo 4. IVE'ye yönelik tutumlarla ilgili ifadeler (1 kesinlikle katılıyorum - 5 kesinlikle katılmıyorum)

\begin{tabular}{|c|c|c|}
\hline Soru & Ortalama & SS \\
\hline IVE, doğal değildir & 1,78 & 1,07 \\
\hline IVE, doğaya saygısızlıktır & 2,49 & 1,34 \\
\hline IVE, dünyadaki mutlu hayvan sayısını azaltacaktır & 2,57 & 1,54 \\
\hline IVE, insanların yenilme ihtimalini artıracaktır, yani yamyamlık meydana gelebilir & 3,04 & 1,47 \\
\hline IVE etiktir & 3,14 & 1,31 \\
\hline IVE, hayvan refahı koşullarını iyileştirir & 2,81 & 1,43 \\
\hline IVE dünyadaki kıtlık sorunlarını çözebilecektir & 2,58 & 1,33 \\
\hline Gelecekte, IVE, normal etlere uygulanabilir bir alternatif olacaktır & 2,70 & 1,31 \\
\hline IVE, küresel ısınmanın çiftçilikle ilgili etkisini azaltacaktır & 2,63 & 1,37 \\
\hline IVE üretiminin geleneksel çiftçiler üzerinde olumsuz etkisi olacaktır & 1,94 & 1,26 \\
\hline
\end{tabular}

Tablo 5. Regresyon katsayıları, P değerleri, Olasılıklar oranı ve güven aralıkları ile cinsiyetten önemli ölçüde etkilenen IVE anketine ortalama erkek ve kadın yanıtları (1: çok daha fazla/kesinlikle katılıyorum/kesinlikle evet; 5: çok daha az/kesinlikle katılmıyorum/ kesinlikle hayır)

\begin{tabular}{|c|c|c|c|c|c|c|}
\hline Soru & Erkek & Kadın & $\begin{array}{l}\text { Regresyon } \\
\text { Katsayısı } \\
(\beta)\end{array}$ & P değeri & 00 & $\% 95$ GA \\
\hline Daha önce IVE terimini uydunuz mu? (1=Evet, 2=Hayır) & 1,69 & 1,65 & 0,79 & $>0,05$ & 1,082 & $0,50-2,33$ \\
\hline $\begin{array}{l}\text { Sizce IVE'nin, normal etle karşılaştırıldığında ne kadar sağlıkı } \\
\text { olduğunu düşünüyorsunuz }\end{array}$ & 4,15 & 3,70 &,- 642 & $<0,05$ & 0,53 & $0,33-0,83$ \\
\hline $\begin{array}{l}\text { Sizce IVE'nin, normal ete kıyasla ne kadar çevre dostu olduğunu } \\
\text { düşünüyorsunuz? }\end{array}$ & 3,00 & 3,26 & ,519 & $<0,05$ & 1,68 & $1,18-2,38$ \\
\hline $\begin{array}{l}\text { Sizce IVE'nin normal etle karşılaştıııldığında ne kadar etik olduğunu } \\
\text { düşünüyorsunuz? }\end{array}$ & 3,56 & 3,63 & ,452 & $<0,05$ & 1,57 & $1,03-2,40$ \\
\hline $\begin{array}{l}\text { Sizce IVE'nin normal et ile karşılaştırıldığında ne kadar çekici } \\
\text { olduğunu düşünüyorsunuz? }\end{array}$ & 3,98 & 3,81 &,- 277 & $>0,05$ & 0,76 & $0,50-1,16$ \\
\hline $\begin{array}{l}\text { Sizce IVE'nin, normal etle karşılaştırıldığında ne kadar lezzetli } \\
\text { olacağını düşünüyorsunuz }\end{array}$ & 4,15 & 4,06 & 171 & $>0,05$ & 1,19 & $0,76-1,85$ \\
\hline IVE denemek ister misiniz? & 3,28 & 2,95 &,- 188 & $>0,05$ & 0,83 & $0,58-1,18$ \\
\hline IVE, doğal değildir & 1,81 & 1,74 & ,310 & $>0,05$ & 1,36 & $0,88-2,11$ \\
\hline IVE etiktir & 3,26 & 3,01 &,- 269 & $>0,05$ & 0,76 & $0,52-1,12$ \\
\hline Gelecekte, IVE, normal etlere uygulanabilir bir alternatif olacaktır & 2,73 & 2,68 &,- 055 & $>0,05$ & 0,95 & $0,72-1,25$ \\
\hline IVE, küresel ısınmanın çiftçilikle ilgili etkisini azaltacaktır & 2,78 & 2,49 &,- 198 & $>0,05$ & 0,82 & $0,60-1,12$ \\
\hline IVE üretiminin geleneksel çiftçiler üzerinde olumsuz etkisi olacaktır & 1,98 & 1,91 &,- 331 & $>0,05$ & 0,72 & $0,48-1,08$ \\
\hline IVE, doğaya saygısızlıktır & 2,34 & 2,64 & ,373 & $<0,05$ & 1,45 & $1,02-2,06$ \\
\hline $\begin{array}{l}\text { IVE, insanların yenilme intimalini artıracaktır, yani yamyamlık } \\
\text { meydana gelebilir }\end{array}$ & 2,98 & 3,10 & ,146 & $>0,05$ & 1,16 & $0,87-1,54$ \\
\hline
\end{tabular}

GA: Güven aralığı; OO: Olasılıklar Oranı

göre daha az lezzetli, daha az çevre dostu olduğunu buna karşın normal ete kıyasla daha ucuz olacağını düşünmüştür. Burada ilginç olan değerlendirme ise IVE'nin gerçekte zoonoz hastalıklar yönüyle risk taşıma olasılığının düşük olmasına rağmen katılımcıların bu konuda ikna olmamasıdır.

Tablo 4'te görüleceği üzere katılımcılar, daha önce yapılmış çalışmalarda (Laestadius ve ark.,
2015; Mancini ve Antonioli, 2019; Tiberius ve ark., 2019; Wilks ve Phillips, 2017) elde edilen sonuçlarla uyumlu bir şekilde, IVE'nin doğallık ile ilgili endişelerinin olduğunu belirtmişlerdir. Ayrıca katılımcılar, IVE'nin normal ete bir alternatif olabileceği konusuna katılmazken dünyadaki kıtlık sorunlarını çözme potansiyeline sahip olduğu konusunda nispeten katılmışlardır. Katılımcılar 
IVE'nin doğaya saygısızlık olduğu veya dünyadaki mutlu hayvan sayısını azaltacağı konusunda aynı fikirdedir. Bununla birlikte, katılımcılar, ortalama olarak, IVE'nin geleneksel çiftçiler üzerinde olumsuz etkileri olacağını da belirtmişlerdir. Tüm bu sonuçlar göz önünde bulundurulduğunda IVE ile hem bağımsız hem de normal ete göre bazı genel kaygılar olmasına rağmen, katılımcıların bazı başlıklarda olumlu sonuçları tespit edebildiklerini görülmektedir. Bununla birlikte, önceki araştırmalarda tanımlandığı gibi (Wilks ve Phillips, 2017; Verbekeve ark., 2015b), bu olumlu sonuçlar daha düşük iken, endişeler daha fazladır.

Cinsiyet, soruların yaklaşık \%30'unda (4/13) farklılıklar göstererek en önemli demografik öngörücü olarak bulunmuştur. Genel olarak bakıldığında, erkeklere kıyasla, kadınların IVE'ye yönelik tutumlarının daha pozitif olduğu belirlenmiştir. Kadınların bir ürün olarak IVE tüketme konusunda daha istekli oldukları ve 4 soru dışında ürün hakkında daha olumlu görüşlere sahip oldukları bulunmuştur. Bulunan bu sonuç ABD'deki erkek bireylerin IVE konusunda daha pozitif bir görüşe sahip olduğunu bildiren Wilks ve Phillips'in (2017) yapmış olduğu çalışmayla farklıdır. Bu durum, et tüketme algısının cinsiyete bağımlı bir şekilde değişebileceğini ifade eden Ruby ve Heine (2011)'nin bildirdiği sonuçla uyumludur. Nitekim normal et, erkek bireyler tarafından IVE'ye karşı savunularak geleneksel alışkanlıklar ön planda tutulmuştur. Tüm tablo göz önünde bulundurulduğunda her ne kadar farklılıklar gözlemlense de cinsiyetin IVE'ye yönelik algıdaki etkilerinin düşük düzeyde olduğu saptanmıştır.

Yapılan anket çalışmamızda verilen cevaplara göre bir diğer öngörücü faktör bireylerin beslenme alışkanlıklarıydı. Yapılan istatiksel analizlerde beslenme alışkanlığı yönünden katılımcıların düşük sayıda sadece balık eti, vegan ve vejeteryan tercih göstermesi sebebiyle sadece kırmızı et ve tavuk eti göz önünde bulundurularak IVE'ye yönelik tutumları dikkate alınmıştır. Elde edilen sonuçlara göre tavuk eti tüketenler kırmızı et tüketenlere nazaran IVE'nin normal ete kıyasla daha çevre dostu olduğunu belirtmişlerdir $(\beta=-, 612, p=0,02, O O=0,64$, (\%95 GA, 0,33-1,24)). Buna karşın kırmızı et tüketenlerin IVE tüketme konusunda tavuk eti tüketenlere nazaran daha istekli oldukları görülmüştür $(\beta=, 866$, $p=0,01, O O=2,38,(\% 95$ GA, 1,41-3,99). Diğer taraftan tavuk eti tüketenler kırmızı eti tüketenlere nazaran küresel ısınmanın çiftçilikle ilgili etkisini azaltacağını belirtmişlerdir $(\beta=-1,025, p=0,01,00=$ 0,36, (\%95 GA, 0,20-0,64). Diğer sorulan sorulara alınan yanıtlar beslenme alışkanlıkları yönüyle istatiksel olarak önemsiz bulunmuştur.

Tavuk eti tüketenler IVE tüketme noktasında daha az istekli görünmektedir. Buna karşılık, et yiyenler, etik/sağlık bakış açılarına bakılmaksızın ürünle daha ilgili görünüyorlardı. Dahası, diyetlerinde bildirilen et yüzdesi daha yüksek olan katılımcılar, daha düşük bir yüzdeye sahip olanlardan daha az pozitif IVE görüşlerini ifade etme eğilimindeydi, ancak ürünle gerçekten ilgilenme istekliliğini bu durum etkilememiştir. Bu, daha fazla et yiyen insanların, IVE gibi normal ete ilişkin daha olumlu bir görüşle ilişkili olabilecek alternatif bir et kaynağına girme konusunda istekli olabileceğini düşündürmektedir. Yine belirgin bir şekilde IVE'nin daha çevreci ve küresel ısınma üzerine etkilerinin daha iyi olacağı konusunda görüş bildiren tavuk eti tüketenlerin IVE tüketimi konusunda daha az istekli olmaları ilginç bir paradoks olarak karşımıza çıkmaktadır. Benzer bir sonuç Wilks ve Phillips (2017) tarafından da bildirilmiştir.

Ankete katılanların gelir düzeyi ile IVE'ye yönelik algılar arasında anlamlı bir ilişki kurulamamıştır.

Tüm bu sonuçlar göz önüne alındığında bireylerin IVE'ye dönük algılarında kompleks bir ilişki olduğu görülmektedir. Bu durum henüz daha yeni bir kavram olan IVE'ye yönelik bireylerin nasıl ve ne şekilde davranacağıyla ilgili olduğundan ileri geldiği düşünülmüştür. IVE'nin gündelik hayatta kullanımının yokluğu ve/veya azlığının yanısıra lezzet, görünüş vb. gibi özelliklerinin bilinmemesi IVE'ye yönelik algılarda daha kuşkulu davranış olarak karşımıza çıkmaktadır. Yine bu çalışmanın ilginç sonuçlarından biri de ankete katılım gösteren kadınların erkeklere göre IVE'ye dönük nispeten daha pozitif algılarıdır. Bu çalışmada IVE'nin kabülünde engel olarak ahlâkî mutlakiyetçiliğin önemli rolü olduğu düşünülmüştür. Bireylerin sahip oldukları gıda tüketimi konusundaki alışkanlıklarının sorgulanması yeni ürünlerin üretimi konusunda önemli bir bariyer olarak görülmektedir. Bu bakımdan toplumsal kabulü teşvik etmek için bu endişeleri nasıl ele alabileceğimiz çözülmesi gereken bir problem olarak görülmüştür. İlerleyen yıllarda bu alanda gerçekleştirilebilecek adımların nasıl karşılanacağı ile ilgili Türkiye çapında yapılması gerekli daha fazla araştırmaya intiyaç duyulduğu düşünülmüştür. Mevcut araştırmamız her ne kadar küçük ölçekli olsa da IVE'ye yönelik algıların araştırıldığı ilk çalışma olması açısından önemlidir.

\section{Kaynaklar}

Bekker GA, Fischer AR, Tobi H, van Trijp HC, 2017: Explicit and implicit attitude toward an emerging food technology: The case of cultured meat. Appetite, 108, 245-254.

Bryant C, Barnett J, 2018: Consumer acceptance of cultured meat: A systematic review. Meat Sci, 143, 8-17. 
Bryant CJ, Szejda K, Deshpande V, Parekh N, Tse B, 2019: A Survey of Consumer Perceptions of Plant-Based and Clean Meat in the USA, India, and China. Front Sustain Food Syst, 3, 11.

Hocquette A, Lambert C, Sinquin C, Peterolff L, Wagner Z, Lebert A, Hocquette J-F, 2015: Educated consumers don't believe artificial meat is the solution to the problems with the meat industry. J Integr Agric, 14, 273-284.

Laestadius LI. Caldwell MA, 2015: Is the future of meat palatable? Perceptions of in vitro meat as evidenced by online news comments. Public Health Nutr, 18, 2457-2467.

Mancini MC. Antonioli F, 2019: Exploring consumers' attitude towards cultured meat in Italy. Meat Sci, 150, 101-110.

Marcu A, Gaspar R, Rutsaert P, Seibt B, Fletcher D, Verbeke W, Barnett J, 2015: Analogies, metaphors, and wondering about the future: Lay sense-making around synthetic meat. Public Underst Sci, 24, 547562.

McLeod A, 2011: World livestock 2011-livestock in food security: Food and Agriculture Organization of the United Nations (FAO).

Post MJ, 2014: Cultured beef: medical technology to produce food. J Sci Food Agric, 94, 1039-1041.

Ruby MB, Heine SJ, 2011: Meat, morals, and masculinity. Appetite, 56, 447-450.

Sharma S, Thind SS, Kaur A, 2015: In vitro meat production system: why and how? I Food Sci Technol, 52, 7599-7607.
Slade P, 2018: If you build it, will they eat it? Consumer preferences for plant-based and cultured meat burgers. Appetite, 125, 428-437.

Stephens N, Di Silvio L, Dunsford I, Ellis M, Glencross A, Sexton A, 2018: Bringing cultured meat to market: Technical, socio-political, and regulatory challenges in cellular agriculture. Trends Food Sci Technol, 78:155-166.

Tiberius V, Borning J, Seeler S, 2019: Setting the table for meat consumers: an international Delphi study on in vitro meat. npj Sci Food, 3, 10.

Tucker CA, 2014: The significance of sensory appeal for reduced meat consumption. Appetite, 81, 168-179.

Verbeke W, Sans P, Van Loo EJ, 2015a: Challenges and prospects for consumer acceptance of cultured meat. J Integr Agric, 14, 285-294.

Verbeke W, Marcu A, Rutsaert P, Gaspar R, Seibt B, Fletcher D, Barnett J, 2015b: 'Would you eat cultured meat?': Consumers' reactions and attitude formation in Belgium, Portugal and the United Kingdom. Meat sci, 102, 49-58.

Wilks M, Phillips CJ, 2017: Attitudes to in vitro meat: A survey of potential consumers in the United States. PloS One, 12, e0171904.

${ }^{*}$ Yazışma Adresi: Alper BARAN

Atatürk Üniversitesi, Teknik Bilimler Meslek Yüksekokulu, Gıda Kalite Kontrol ve Analizi Programı, Erzurum, Türkiye.

e-mail: alper.baran@atauni.edu.tr 


\section{EK 1}

\section{Ankette sorulan soruların listesi}

Katılımcılara ankete katılımdan önce aşağıdaki metini okuması sağlanmıştır.

"Bu ankette in vitro et üretimine karşı olan tutumlarının incelenmesi amaçlanmaktadır. Sorulan sorularda kişisel önem arz eden bilgiler yer almamakta olup elde edilecek veriler sadece akademik ortamda paylaşılacaktır."

\section{Sorular}

S1 Çalışmanın koşullarını okudum ve anladım. Katılımın tamamen gönüllü ve isimsiz olduğunu onaylıyorum. OEvet (2)

OHayır (1)

Hayır'ı seçen katılımcıların değerlendirmeleri dikkate alınmamıştır.

S2 Lütfen yaşınızı belirtin (yıl olarak).

S3 Cinsiyetiniz nedir?

OMale (1)

OFemale (2)

S4 Yıllık geliriniz nedir?

O2000-3000 TL (1)

O3000-4000 TL (2)

04000-5000 TL (3)

O6000-7000 TL (4)

O8000-9000 TL (5)

O10000 TL ve üzeri (6)

S5 Gıda tüketme alışkanlıklarınız nelerdir?

OKırmızı Et (1)

OSadece tavuk eti (2)

OSadece balık eti (3)

OVejeteryan (Sağlık açısından bazen et tüketir) (4)

OVegan (Hiçbir şekilde et tüketmez) (5)

S6 Diyetinizin yaklaşık yüzde kaçı etten oluşuyor?

\begin{tabular}{|l|l|l|l|l|l|l|l|l|l|l|}
\hline & $1(1)$ & $2(2)$ & $3(3)$ & $4(4)$ & $5(5)$ & $6(6)$ & $7(7)$ & $8(8)$ & $9(9)$ & $10(10)$ \\
\hline$\% 10$ & 0 & 0 & 0 & 0 & 0 & 0 & 0 & 0 & 0 \\
\hline
\end{tabular}

S7 Daha önce "Invitro et (In vitro et)" terimini duydunuz mu?? Evet (1) Hayır (2)

\begin{tabular}{l|l}
\hline & 0
\end{tabular}

Bir sonraki soruları cevaplayabilmek için bu kısmı mutlaka okumalısınız. In vitro et (Invitro et), hiçbir zaman canlı bir hayvanın bir parçası olmayan, ancak bunun yerine hayvanların kas kök hücreleri kullanan bir laboratuarda yetiştirilen bir hayvan eti ürünüdür. Bu kök hücreler, hayvana zarar vermeden çıkarılarak elde edilir. In vitro et aynı zamanda kültüre edilmiş et, schmeat veya sentetik et olarak da adlandırılır. Ağustos 2013'te, bilim adamları dünyanın ilk Laboratuvar ortamında üretilerek elde edilen etten hazırlanmış hamburger köftesini tanıtmıştır. Halen ticari olarak temin edilememektedir, ancak gelecekteki potansiyel et üretim tekniği olarak tanıtılması için araştırmalar yapılmaktadır. Dünyanın ilk in vitro et hamburgeri Londra'da tanıtılmıştır.

S8 Sizce in vitro etin, çiftlik etiyle karşılaştırıldığında ne kadar sağlıklı olduğunu düşünüyorsunuz?

OÇok daha fazla sağlıklı (1)

OBiraz daha sağlıklı (2)

ONe daha sağlıklı ne de daha az sağlıklı (3)

OBiraz daha az sağlıklı (4)

OÇok daha az sağlıklı (5)

S9 Sizce In vitro etin çiftlik etiyle karşılaştırıldığında ne kadar doğal olduğunu düşünüyorsunuz? OÇok daha fazla doğal (1)

OBiraz daha doğal (2)

ONe daha doğal ne de daha az doğal (3)

OBiraz daha az doğal (4)

OÇok daha az doğal (5) 
S10 Sizce In vitro etin, çiftçilik ete kıyasla ne kadar çevre dostu olduğunu düşünüyorsunuz?

OÇok daha fazla çevre dostu (1)

OBiraz daha çevre dostu (2)

ONe daha çevre dostu ne de daha az çevre dostu (3)

OBiraz daha az çevre dostu (4)

OÇok daha az çevre dostu (5)

S11 Sizce In vitro etin çiftlik etiyle karşılaştırıldığında ne kadar etik olduğunu düşünüyorsunuz?

OÇok daha fazla etik (1)

OBiraz daha etik (2)

ONe daha etik ne de daha az etik (3)

OBiraz daha az etik (4)

OÇok daha az etik (5)

S12 Sizce In vitro etin çiftlik eti ile karşılaştırıldığında ne kadar çekici olduğunu düşünüyorsunuz?

OÇok daha fazla çekici (1)

OBiraz daha çekici (2)

ONe daha çekici ne de daha az çekici (3)

OBiraz daha az çekici (4)

OÇok daha az çekici (5)

S13 Sizce In vitro etin, çiftlik etiyle karşılaştırıldığında ne kadar lezzetli olacağını düşünüyorsunuz?

OÇok daha fazla lezzetli (1)

OBiraz daha lezzetli (2)

ONe daha lezzetli ne de daha az lezzetli (3)

OBiraz daha az lezzetli (4)

OÇok daha az lezzetli (5)

S14 Hayvanlardan insana bulaşıcı hastalık transferi için in vitro et, çiftlik eti karşılaştırıldığında riskinin ne kadar olacağını düşünüyorsunuz?

OÇok daha fazla riskli (1)

OBiraz daha riskli (2)

ONe daha riskli ne de daha az riskli (3)

OBiraz daha az riskli (4)

OÇok daha az riskli (5)

S15 Küresel düzeyde, et talebinin karşılanmasında laboratuvarda üretilen etlerin kullanılması, çiftlik etinden daha ucuz veya daha pahalı olacağını düşünüyor musunuz?

OÇiftlik etinden çok daha ucuz (1)

OÇiftlik etinden biraz daha ucuz (2)

OÇiftlik etinden ne daha az ne de daha ucuz (3)

OÇiftlik etinden biraz daha pahalı (4)

OÇiftlik etinden çok daha pahalı (5)

S16 in vitro et denemek ister misiniz?

OEvet kesinlikle (1)

OEvet belki (2)

OEmin değilim (3)

OHayır muhtemelen değil (4)

OHayır kesinlikle olmaz (5)

"In vitro et denemek ister misiniz" sorusunun cevabı eğer Hayır ise anket bitirildi. Evet ise sonraki sorular soruldu.

S17 Düzenli olarak in vitro et yer misiniz?

OEvet kesinlikle (1)

OEvet belki (2)

OEmin değilim (3)

OHayır muhtemelen değil (4)

OHayır kesinlikle olmaz (5) 
S18 Çiftlik etinin yerine in vitro et yemeye istekli misiniz?

OEvet kesinlikle (1)

OEvet belki (2)

OEmin değilim (3)

OHayır muhtemelen değil (4)

OHayır kesinlikle olmaz (5)

S19 Eğer In vitro et satın alacak olsaydınız, çiftçilik etine kıyasla ne kadar ödemek isterdiniz?

ODaha fazla (1)

OBiraz daha (2)

ONe fazla ne eksik (3)

OBiraz daha az (4)

ODaha az (5)

Bu kısımdaki sorular tüm katılımcılar için sorulmuştur.

S20 Neden in vitro et denemek istemiyor olabilirsiniz? Uygun olanları seçin.

OEtik kaygılar (1)

ODini sebepler (2)

OÜrünün tadı/görünüşü (3)

ODiğer (4)

S21 Şu anda ne tür et yiyorsunuz?

OBalık ve deniz ürünleri (1)

OKümes hayvanları (2)

OPastırma, salam, sosis, kavurma (3)

OSı̆̆ır eti (4)

S22 Laboratuvar yöntemiyle üretilmiş olsaydı ne tür et yerdiniz?

OBalık ve deniz ürünleri (1)

OKümes hayvanları (2)

OPastırma, salam, sosis, kavurma (3)

OSı̆̆ır eti (4)

S23 Lütfen aşağıdaki ifadelere ne derece katıldığınızı değerlendirin.

\begin{tabular}{|c|c|c|c|c|c|}
\hline & $\begin{array}{r}\text { Kesinlikle } \\
\text { katılıyorum (1) }\end{array}$ & $\begin{array}{c}\text { Biraz } \\
\text { katılıyorum (2) }\end{array}$ & \begin{tabular}{l}
\multicolumn{1}{c}{$\mathrm{Ne}$} \\
katılıyorum ne \\
katılmıyorum (3)
\end{tabular} & $\begin{array}{c}\text { Biraz } \\
\text { katılmıyorum (4) }\end{array}$ & $\begin{array}{r}\text { Kesinlikle } \\
\text { katılmıyorum (5) }\end{array}$ \\
\hline $\begin{array}{rrrr}\text { in vitro et, doğal } \\
\text { değildir }\end{array}$ & 0 & 0 & 0 & $O$ & 0 \\
\hline $\begin{array}{l}\text { in vitro et, doğaya } \\
\text { saygısızlıktır }\end{array}$ & 0 & 0 & 0 & 0 & 0 \\
\hline $\begin{array}{l}\text { In vitro et, dünyadaki } \\
\text { mutlu hayvan sayısını } \\
\text { azaltacaktır }\end{array}$ & $\mathrm{O}$ & $\mathrm{O}$ & $\mathrm{O}$ & $\mathrm{O}$ & $\mathrm{O}$ \\
\hline \begin{tabular}{l}
\multicolumn{1}{c}{ In vitro et, insanların } \\
yenilme $\quad$ intimalini \\
artıracaktır, yani yamyamlık \\
meydana gelebilir \\
\end{tabular} & $\mathrm{O}$ & $\mathrm{O}$ & $\mathrm{O}$ & $\mathrm{O}$ & $\mathrm{O}$ \\
\hline In vitro et etiktir & $\mathrm{O}$ & $\mathrm{O}$ & $\mathrm{O}$ & $\mathrm{O}$ & $\mathrm{O}$ \\
\hline $\begin{array}{l}\text { in vitro et, hayvan } \\
\text { refahı koşullarını iyileştirir }\end{array}$ & $\mathrm{O}$ & $\mathrm{O}$ & $\mathrm{O}$ & $\mathrm{O}$ & $\mathrm{O}$ \\
\hline $\begin{array}{l}\text { In vitro et dünyadaki } \\
\text { kıtlık } \\
\text { çözzebilecektir }\end{array}$ & $O$ & $\mathrm{O}$ & $\mathrm{O}$ & $\mathrm{O}$ & $\mathrm{O}$ \\
\hline $\begin{array}{l}\text { Gelecekte, In vitro et, } \\
\text { çiftlik etlerine uygulanabilir } \\
\text { bir alternatif olacaktır }\end{array}$ & $\mathrm{O}$ & $\mathrm{O}$ & $\mathrm{O}$ & $\mathrm{O}$ & $\mathrm{O}$ \\
\hline $\begin{array}{l}\text { in vitro et, küresel } \\
\text { Isınmanın çiftçilikle ilgili } \\
\text { etkisini azaltacaktır }\end{array}$ & 0 & 0 & $\mathrm{O}$ & 0 & $\mathrm{O}$ \\
\hline $\begin{array}{l}\text { In vitro et üretiminin } \\
\text { geleneksel çiftçiler üzerinde } \\
\text { olumsuz etkisi olacaktır }\end{array}$ & $\mathrm{O}$ & $\mathrm{O}$ & $\mathrm{O}$ & $\mathrm{O}$ & $\mathrm{O}$ \\
\hline
\end{tabular}

